\title{
Importance Developing E-Learning for High School Students In Sragen Regency, Central Java
}

\author{
Muryani, C. ${ }^{1}$, Sarwono ${ }^{1}$, Nugraha, S. $^{1}$ \\ ${ }^{1}$ The Faculty of Teacher Training and Education Sebelas Maret University Indonesia \\ Corresponding email: chatarinamuryani@staff.uns.ac.id
}

\begin{abstract}
In the current era of IT advancement, innovation in the field of learning needs to be done. Besides improving the quality of learning, the use of IT in education can increase student interest in the subjects. This research is the analysis stage of developing Geography e-learning for Sinior High School in Sragen Regency using ADDIE model. Data collection was done by interview using questionnaires toward 20 teachers and 416 students in 11 public and private Senior High Schools in Sragen Regency. The results of the analysis of geography teachers respons indicate that most of the geography teachers in Sragen regency were wellinformed and had utilized IT in classroom learning, adding learning resources from the internet and other sources, willing to teach using e-learning, expecting elearning material equipped with maps, imagery, video and animation which was developed. From the analysis of the students respons, students argued that most of the geography teachers in Sragen Regency had utilized the learning resources and learning media from the internet and use varied learning models. Nevertheless there are $36 \%$ who think that geography lesson was boring and most students agreed to use e-learning for geography lesson. The main obstacle in e-learning lesson in Sragen regency was the availability of computer facilities and internet network especially in private schools.
\end{abstract}

Keywords: e-learning; readiness; geography; Senior High School

DOI: http://dx.doi.org/10.20961/ijpte.v1i2.14884

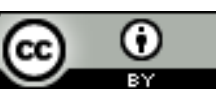




\section{INTRODUCTION}

Education is not only aims to transfer of knowledge, but also improve the ability of analysis, synthesis, communication and connecting the science with the real world. This can be achieved if the learning process is supported by technology (Cesar and Gaible, 2008). The new paradigm that emerges is related to the learning process that no longer describes face-to-face meetings in the classroom even though the concept of social interaction in it has been retained and has been widely accepted and has had an impact on human life (Tri Darmayanti et al., 2007). There are various models of learning by using computers such as: elearning (electronic learning) Computer Assisted Instruction (CAI), Computer Based Instruction (CBI), and e-teaching (electronic teaching).

Recently, e-learning considers as a critical element in the educational system which imposed an innovative shift in the learning environment (Nagarajan and Jiji, 2010). An effective implementation of e-learning can border the educational opportunities and enhance a positive attitude toward the learning process and helps students in developing skills they need for the 21st century (Phillips., 2002).

According to Ellaway and Masters (2008), e-learning (often referred to as online learning) is not just broadcasting documents in electronic format to students via the internet. E-learning includes a pedagogical approach that usually aspires to be flexible, engaging and learner-centered; that encourages interaction (staff-staff, staff-student, student-student), and collaboration and communication, often asynchronously (though not exclusively so).

A number of instruments have been developed to assess e-learning readiness. Aydin and Tasci (2005) developed an E-Learning Readiness Survey (ELRS) at the company. The results confirmed that gender, age, education level, and computer experience had no effect on participants' overall perceptions of institutional readiness. Pillay, Irving, and Tones (2007) developed the students' readiness instrument; Tertiary for Online Learning (TSROL). The result showed that students' preference, technical skills and computer self-efficacy need to be improved by adopting a more multidimensional interpretation of preference and learning attitudes toward computers. Sadik (2007) developed an instrument to measure individual readiness to develop and implement e-learning (IRDI-EL). The study reveals that competencies, experiences and attitudes affect the readiness of individual faculty to successfully develop and implement an e-learning approach. Self-Assessment E-Learning (ELRSA) was developed by Watkins, Leigh, and Triner (2004) to assess the readiness of individual learners who have no previous e-learning experience. The researchers argued that e-learning readiness is influenced by access to technology, skills and online relationships, motivation, and Audio/video online.

Parlakkılıç (2015) said that the e-learning readiness dimensions have been grouped into eight dimensions based on previousresearches, there are (1) Technological skills, (2) Online learning style, (3) Equipment/infrastructure, (4) Attitude readiness, (5) Human resources, (6) Environmental readiness, (7) Cultural readiness, and (8) Financial. 
E-learning that will be developed is specifically for learning geography in Senior High SchoolsinSragen. The purpose of this study is to analyze the level of readiness of Senior High School teachers and students in Sragen district in utilizing developed e-learning.

\section{METHODS}

This research is a survey research. Data collection was done through field observation and interview using questionnaires. The indicators of e-learning readiness was using 8 dimensions in accordance with Parlakkıllıç (2015) opinion namely (1) Technological skills readiness, (2) Online learning style readiness, (3) Equipment / infrastructure readiness, (4) Attitude readiness, (5) Human Resources readiness, (6) Environmental readiness, (7) Cultural readiness, and (8) Financial readiness. Respondents consist of two groups: group of teachers and group of students. A total of 20 teachers and 416 students from 11 public and private schools were successfully interviewed. Teacher samples were taken by two geography teachers per school, but there were two schools with only one geography teacher. One class per school was taken as a sample, selected class was grade $\mathrm{X}$ at random. The questionnaire instrument consists of 8 question groups based on the e-learning readiness criteria above, each group consists of 3 items of question. Problems have been tested and measured the validity. The collected data was analyzed quantitatively. In each question item there are 4 answer options, answer (a) score 4, answer (b) score 3, answer (c) score 2 and answer (d) score 1. Obtaining scores of respondents' answers then classified into 3 readiness classes high, medium and low.

\section{RESULT}

Based on the results of field observations and interviews using questionnaires, it can be reported as follows:

\section{Technological skills readiness}

It measures the readiness of users from the mastery of computer and internet technology. Technological skills readiness is measured by internet access skills, experience of using the internet as a source of learning, and experience of assigning tasks and doing tasks from the internet by geography teachers and students of Sragendistrict. The results of interviews with teachers showed that internet access skills score was 58, experience using the internet as a source of learning score was 62, the experience of giving task through internet score was 52, with the total score of 172 (medium category). The results of interviews with students showed that the score of internet access skills was 1245, experience scores using the internet as learning resources was 1091, experience working on the task in internet score was 1136, with total score of 3472 (medium category). 
From this result it was still needed to increase technological skills readiness from medium into high.

\section{Online learning style readiness.}

This is defined as the readiness of learners in terms of time commitment, discipline and interest in e-learning. In this study, online learning style readiness is measured by the interest of teachers and students in learning through e-learning, the willingness of teachers and students through the e-learning process, and the willingness of teachers and students to follow the training of e-learning utilization for geography learning. The result of interview with teacher showed, the score of e-learning interest was 69 , score of willingness to use e-learning was 74 , score of willingness to train was 68, total score of online learning style readiness for geography teacher was 211 (high category). The result of interview with student showed that score of e-learning interest was 1442, score of willingness to use elearning was 1411, training willingness score was 1396, with total score of online learning style readiness for student was 4249 (high category).

\section{Equipment readiness}

This dimensionis defined as proper equipment/infrastructure readiness, provision of technical support, e-learning content delivery, and LMS adopted by the organization. In this study equipment readiness was measured by the availability of computers for students in schools, the availability of internet networks in schools, and the availability of e-learning content. The result of interview with teachers and studentsas well as observation about equipment readiness was, teachers' answer score for computer availability at school was 68, internet network availability at school was 55, availability of e-learning content was 69 , so the total score of equipment according to teacher was 192 (Medium category). While the result of interview with student showed, school computer availability score was 1227, school internet network availability score was 1085, teachers' elearning material readiness was 1095, with total score of 3408 (medium category).

\section{Attitude readiness}

User attitudes are factors that influence the use of technology. The attitude readiness in this research involves trust, enjoyment, interest, motivation, and selfdevelopment. In this study, attitude readiness was measured by the parameters of willingness of teachers and students to learn internet, the willingness of teachers and students to learn using e-learning, the willingness of teachers and students to follow the e-learning training. Based on interviews with teachers, the score for internet use in learning was 68, teacher availability score of using e-learning in learning was 74, teacher willingness to follow e-learning training was 73, overall score for attitude readiness teacher was 215 (high category). The result of the interview with the students showed the score of internet utilization in learning was 
1095, the score of students' willingness to use e-learning in the learning of geography was 1354, the score of students willingness to follow the e-learning training was 1279, with the total score of 3728 (medium category).

\section{Human resources readiness}

This is the availability and support of human resources. In this research the availability of resources have been well prepared by researchers as a developer of e-learning, including personnel for the manufacture of moodle NGOs by ICT FKIP team Sebelas Maret University, operational personnel from SMA-1 Sragen to be trained by ICT team UNS, and Module development team of UNS students with the geography teachers of Sragen Regency.

Table 1 Human Resource Availability

\begin{tabular}{cccc}
\hline Human resources & F & $\begin{array}{c}\text { Student } \\
\text { Score }\end{array}$ & Total \\
\hline Experts (ICT UNS) & 3 & 3 & 9 \\
Operational Personnel (school) & 2 & 3 & 6 \\
Module Developer (teachersand university students) & 28 & 4 & 112 \\
Additional Resources & 3 & 3 & 9 \\
\hline Total & & & 136 \\
\hline
\end{tabular}

Source: primer data

The above table was for the parameter of human resources readiness with score of 136 with the category "medium".

\section{Environmental readiness}

This involves overall institutional preparedness in terms of Government policy, the role of mass media, and intellectual property regulations. Learning using elearning model has been widely developed in Indonesia and in this case received support both by the government and the leadership of user agencies. In this case the researchers in cooperation with the Geography Teachers Assembly in Sragen Regency and permission by schools in the Sragen regency. However, because elearning for high school level has not been developed, for environment readiness is considered "medium".

\section{Cultural readiness}

In this study cultural readiness was measured by the frequency of teachers assigning tasks and students doing the tasks from the internet, the frequency of using the Internet as a medium of learning geography and interest of teachers and students in learning using e-learning. Based on the interviews, it was obtained the results, the scores of teacher assignment using the internet was 68, the score of internet use as a medium of learning was 50, teacher interest in using e-learning was 80, total score was 198 (medium category). 


\section{Financial readiness}

This concept refers to whether the trainee or institution is financially ready for the e-learning program. In this research the financing of LMS preparation and elearning content was funded from research fund of Sebelas Maret University. The sustainability of this program is funded by Geography Teachers Association. The problem was, there were some schools that the number of computers was not adequate, and there was even a school that has not had the internet network. Researchers rate for financial readiness included in the category 'medium'.

In summary, the results of interviews of teachers and students' readiness in the application of e-learning geography subjects in Sragen regency were:

Table 2 E-learning readiness categories for learning geography in High Schools in Sragen

\begin{tabular}{ccc}
\hline Indicator & Teachers & Students \\
\hline Technological skills readiness & Medium & Medium \\
Online learning style readiness & High & High \\
Equipment readiness & Medium & Medium \\
Attitude readiness & High & Medium \\
Human resources readiness & Medium & Medium \\
Environmental readiness & Medium & Medium \\
Cultural readiness & Medium & Medium \\
Financial readiness & Medium & Medium \\
\hline
\end{tabular}

Source: analysis primer data

\section{DISCUSSION}

Measurement of e-learning readiness is essential to support the successful of Elearning implementation, without having to spend the cost, effort and time (Hetty Rohayani.AH, 2015). Measurement of e-learning readiness enables institutions to design systems that are appropriate to the conditions of the institutions themselves for successful implementation (Oketch, 2013). Each institution has a different level of readiness. Therefore, each institution must be more careful in determining what factors will be an important factor to focus on their e-learning readiness level, in order to obtain accurate information, reflecting the actual condition of their institutions.

From the results of the interview,it showed that High Schools in Sragen regency had the potential to implement e-learning but in some cases still needed to be improved. Teachers' and students' high support was a very important potential because they were the main actors in the application of e-learning. The ability of teachers and students in internet technology and computer adequacy level for students were the main thing that should get attention in the development of elearning in Sragen regency. Most teachers and students were already familiar with Internet technology, but there were some teachers and a small percentage of students who need to improve their skills. 
In the early stages,this e-learning model could take place because it get expert and financial support from the researchers. What must be prepared is the sustainability of this program due to the limited human resources and financial support. This is in accordance with the opinion of Jaflah et.al (2016) that the implementation of elearning requires a cost that is not small.

\section{CONCLUSION}

The results of the analysis of geography teachers' response indicatedthat technological skills readiness was in medium category, online learning style readiness was in high category, equipment/infrastructurereadiness was inmedium category, attitude readiness was in medium category, human resources readiness was inmedium category, environmental readinesswas in medium category, cultural readiness was in medium category, and financial readiness was also in medium category. Over all, the teachers' readiness was in medium category.

From the analysis of the students' response indicated that technological skills readiness was in medium category, online learning style readiness was in high category, equipment/infrastructurereadiness was inmedium category, attitude readiness was in high category, human resources readiness was inmedium category, environmental readinesswas in medium category, cultural readiness was in medium category, and financial readiness was also in medium category. Over all, the students' readiness was in medium category.

\section{ACKNOWLEDGEMENT}

Gratitude is given to LPPM Sebelas Maret University who has funded this research through research grant of PNBP fund source.

\section{REFERENCES}

Aydin, C.H. \&Tasci, D. (2005). Measuring readiness for e-learning: Reflections from an emerging country. Educational Technology \& Society, 8(4), 244-257

Cesar A. A. Nunes and Edmond Gaible.2008. "Development of Multimedia Materials”.The LaboratorioDidatico Virtual (LabVirt) project of the Universidade de São Paulo (USP).

Hetty Rohayani. AH, Kurniabudi, Sharipuddin. 2015. A Literature Review: Readiness Factors to measuring e-Learning Readiness in Higher Education. Procedia Computer Science 59 : $230-234$

Jaflah Al-Ammary, Zainab Mohammed and Fatima Omran. E-Learning Capability Maturity Level in Kingdom of Bahrain. TOJET - April 2016, volume 15 issue 2

Nagarajan, P. and Jiji, W. (2010), “Online Educational System (e- learning)”, International Journal of u- and e-Service, Science and Technology, 3(4), 37-48.

Oketch, H. A. E-learning Readiness Assessment Model In Kenyas’ Higher Education Institutions: A Case Study Of University Of Nairobi (Doctoral dissertation, University of Nairobi); 2013.

Parlakkılıç (2015). E-Learning Readiness in Medicine: Turkish Family Medicine (FM) Physicians Case. 
Phillips, V. (2002), “Why does corporate e-learning fail? Virtual University Gazette, June

Pillay, H., Irving, K., \& Tones, M. (2007). Validation of the diagnostic tool for assessing tertiary students' readiness for online learning. Higher Education Research \& Development, 26(2), 217-234.

Rachel Ellaway \& Ken Masters. 2008. AMEE Guide 32: E-Learning in Medical Education, Part 1: Learning, teaching and assessment. Medical Teacher 30: 455-473

Sadik, A. (2007). The readiness of faculty members to develop and implement ELearning: The case of an Egyptian university. International Journal of ELearning, 6(3), 433-453.

Tri Darmayanti, Made Yudhi S. Dan Boedhi Oetojo. (2007). E-Learning Pada Pendidikan Jarak jauh: Konsep yang Mengubah Metode Pembelajaran di Perguruan Tingg Di Indonesia

Watkins, R., Leigh, D., \&Triner, D. (2004). Assessing readiness for e-learning. Performance Improvement Quarterly, 17(4), 66-79 